\title{
La Independencia de Venezuela, una historia mitificada y un paradigma heroico/
}

\author{
The Independence of Venezuela. History \\ as a myth and the heroic paradigm
}

Frédérique Langue

CNRS-Mascipo, París, Francia

Desde la perspectiva de la historia de las ideas y de la historia de las representaciones, este trabajo intenta analizar el uso del mito bolivariano en la historia de Venezuela, ubicándolo en el tiempo largo, hasta llegar al imaginario político de la "República Bolivariana”. Muestra cómo, más allá de la consagrada cronología independentista y de la historiografía patria, asoman temas y pasiones muy a menudo olvidados de la historia académica, aunque si rescatados por une nueva historia oficial. De ahí la necesidad de llegar a un boceto "oportuno" del héroe, dejando de lado hechos petrificados y hasta santificados.

Palabras ClaVE: Sensibilidades (historia de las); Historia oficial; Historia republicana; Venezuela, memoria de; Mantuanos; Bolívar, mito: Chávez (Hugo); Revolución bolivariana.

This essays aims to analyze the use of bolivarian myths in Venezuelan history from point of view of the history of ideas and representations. So its focuses on long term interpretation in order to emphasize the political imaginary of Bolivarian Republic. It points out to the fact that, along with Independence consecrated chronology and homeland centered historiography, come up matters and passions frequently forgotten by academic history but recovered by the new official history.

KeYwords: Sensibilities (history of); Official History: Republican History; Venezuela, Memory of; Colonial Aristocracy; Bolivar, Myth; Chávez (Hugo); Bolivarian Republic. 
En el transcurso del año 2008, el representante más prestigioso de la historia de las ideas - y de lo que se conociera en su tiempo como historia de las mentalidades, ahora de las "representaciones"-, Elías Pino Iturrieta, discípulo de José Gaos, realizó un llamamiento para hacer "un boceto oportuno de Bolívar". Las intervenciones de los intelectuales venezolanos en el debate político se han hecho más frecuentes en estos últimos años, para culminar en una movilización en defensa de la democracia (Movimiento 2-D fundado en abril del 2008 para contrarrestar un "proyecto político totalitario, derrotado civilmente el 2 de diciembre de 2007"). ${ }^{1}$ Desde un principio, y especialmente en su libro El divino Bolívar, E. Pino se empeñó en desmenuzar, en devanar, más que denunciar ciegamente, los usos de la historia oficial y especialmente de las referencias al mayor protagonista de la "primera" Independencia nacional, Simón Bolívar, por los gobiernos de Venezuela, República Bolivariana incluida. No se trata aquí de juzgar —no es este el propósito del historiador de oficio- ni mucho menos de tomar partido en una contienda ideológica cuyos tejemanejes sobrepasan los límites de las fronteras nacionales y cuyo funcionamiento se asemeja al de las creencias, como lo evidencia la polarización de la opinión pública, tanto dentro como fuera de esa "nación llamada Venezuela", según la expresión acuñada por G. Carrera Damas. ${ }^{2}$

1 L. Capdevila: "Les temporalités de l'événement en histoire", en D. Alexander; M. Frédéric; S. Parent et alt: Que se passe-t-il? Evénements, sciences húmaines et littérature, Rennes, PUR, 2004, pp. 79-89. E. Pino Iturrieta: "Los mitos políticos se gastan”, Tal Cual Digital, 1 de octubre de 2007. M. Ferro: Le ressentiment dans l'histoire comprende notre temps, Paris, Odile Jacobs, 2007. Luis Castro Leiva: De la patria boba a la teología bolivariana, Caracas, Monte Avila, 1987. "Y además presidente del PSUV", Tal Cual, 23 de febrero de 2008. Personalismo o liderazgo democrático. El caso de Rómulo Betancourt: Estudio preliminar de Juan Carlos Rey, Caracas, Fundación Rómulo Betancourt, Serie Cuadernos de Ideas Políticas, N. ${ }^{\circ}$ 5, 2007. E. Pino Iturrieta: Nada sino un hombre. Los orígenes del personalismo en Venezuela, Caracas, Editorial Alfa, 2007. Reseñado por: Frédérique Langue: en Nuevo Mundo Mundos Nuevos, n. ${ }^{\circ}$ 8, 2008: http://nuevomundo.revues.org/index 32173.html, p. 302, y del mismo autor: Las ideas de los primeros Venezolanos, Caracas, Monte Ávila Editores Latinoamericana, 1992. Diego Bautista Urbaneja: La idea política de Venezuela 1830-1870, Caracas, Cuadernos Lagoven, Serie Cuatro Repúblicas, 1988. Escritos de T. Lander en Pensamiento liberal del siglo XIX (antología), selección y estudio preliminar de Inés Quintero, Caracas, Monte Ávila Editores, Biblioteca del pensamiento venezolano José Antonio Páez, 1992.

2 Sobre la problemática del estatuto del historiador del tiempo presente, véase Frédérique Langue: "Cuando la calle arde y el aula reflexiona. La historia inmediata de Venezuela, métodos y cuestionamientos", en Domingo Irwin y Frédérique Langue (coords.): Militares y sociedad en Venezuela, Caracas, UCAB-UPEL, 2003, pp. 225-253 y "El acontecer histórico en la historia reciente de Venezuela: algunas reflexiones en torno a una fábrica de emociones para el tiempo presente", en Domingo Irwin y Frédérique Langue (coords.): Militares y poder en Venezuela. Ensayos históricos relacionados con las relaciones civiles y militares venezolanas, Caracas, UCAB-UPEL, 2005, 
Tampoco se trata de darles un repaso a las últimas y muy oportunas entregas de la historiografía venezolanista acerca de la ruptura originaria de la Independencia o de intentar proponer un balance de la extensa y consensuada producción historiográfica (ocasionalmente hagiográfica en la medida en que patria, pueblo y héroes se convierten en ejes interpretativos firmemente asentados en la vertiente nacionalista y, por lo tanto, en un modélico discurso referido a la nación) sobre un periodo que los especialistas coinciden en calificar de "guerra civil" (G. Carrera Damas). ${ }^{3}$ Más allá del tortuoso camino de reversión de la soberanía a la nación, marcado además por fuertes disimilitudes regionales, se trata de analizar, en la larga duración, un proceso histórico de singular novedad y de excepcional mediatización en la historia de las ideas, vinculado a la vez con una insuperable tradición "criolla" y forjador de lo que se adelanta como una "segunda Independencia", tanto del país como del continente. Dicho de otra manera, se intentará relacionar presente y pasado remoto para comprender mejor las declinaciones actuales de un culto que se originó en la Revolución de Independencia, e incluso de un mito en cuanto relato fundacional de índole identitaria e ideológica ejemplificado hoy como bolivarianismo. Por eso mismo cabría resaltar, dentro de ese verdadero andamiaje colectivo, la vertiente reveladora de un tiempo sagrado y hasta la orientación mesiánica del discurso bolivariano, si nos ubicamos en la perspectiva de Mircea Eliade. ${ }^{4}$

pp. 15-28. Fernando Ochoa Antich: "Falsificar la historia", El Universal, 5 de octubre de 2008. François-Xavier Guerra: "La ruptura originaria: mutaciones, debates y mitos de la Independencia", en Izaskun Álvarez Cuartero y Julio Sánchez Gómez (eds.): Visiones y revisiones de la Independencia Americana, Salamanca, Ediciones Universidad, 2003, pp. 89-110. Germán Carrera Damas: Una nación llamada Venezuela, Caracas, Monte Ávila, 1984; y El culto a Bolívar, Caracas, Grijalbo, 1989 (reed. Alfadil Ediciones, 2005). Domingo Irwin y Luis Alberto Buttó: “'Bolivarianismos’ y Fuerza Armada en Venezuela. Una mirada desde las ciencias sociales", Nuevo Mundo Mundos Nuevos, n. ${ }^{\circ}$ 6, 2006: http://nuevomundo.revues.org/index1320.html.

3 Síntesis recién publicadas sobre el periodo: Manuel Chust y José Antonio Serrano (eds.): Debates sobre las independencias iberoamericanas, Madrid-Frankfurt, Iberoamericana/Estudios AHILA, 2007; Izaskun Álvarez Cuartero y Julio Sánchez Gómez (eds.): Visiones y revisiones de la Independencia americana. La Independencia de América: la Constitución de Cádiz y las Constituciones Iberoamericanas, Salamanca, Ediciones Universidad, 2007; Juan Marchena y Manuel Chust (eds.): Por la fuerza de las armas. Ejército e independencias en Iberoamérica, Castellón, Universidad Jaume I, 2008. Sobre el factor regional en el proceso independentista venezolano, Frédérique Langue: "Las elites venezolanas y la revolución de Independencia", Nuevo Mundo Mundos Nuevos, "BAC", 2005, en http://nuevomundo.revues.org/index1181.html y: "La representación venezolana en las Cortes de Cádiz: José Domingo Rus", Nuevo Mundo Mundos Nuevos, "BAC”, 2005, http://nuevomundo.revues.org/index1153.html

4 Mircea Eliade: Mitos, sueños y misterios: Barcelona, Cairos, 2001. 
Unas observaciones bastan sin embargo para tomar la medida de la cuestionada pertinencia del mito bolivariano en su forma actual y la manera como se ha ido desvirtuando e incluso falsificando la figura heroica de Bolívar en manos de los "sacristanes de la actualidad" (E. Pino): la procedencia social del héroe, figura notable del mantuanaje - la aristocracia blanca criolla - portador, como subrayó E. Pino Iturrieta, de un "conjunto de valores propios de una ortodoxia de cuño hispánico". Los mantuanos de la "Colonia" - los "grandes cacaos"- ejercen en efecto su autoridad sobre castas - la "multitud promiscual" de los "pardos"- y esclavos por mandato de Dios. Son los llamados "padres de familia", ejemplificados en los sermones y recordatorios espirituales, y hasta en las Constituciones sinodales de la Provincia. ${ }^{5}$ Tienen un derecho "exclusivo y excluyente" al manejo de influencias y bienes materiales. De tal forma que el héroe da sus primeros pasos entre la "gente principal", se va formando en el estamento más encumbrado y alejado de las vivencias del pueblo y de la "gente de color quebrado". En el caso del héroe, la procedencia no significa sin embargo "petrificación, sino evolución hacia formas de republicanismo cuya implantación se pretende a duras penas", por más que el mantuano Bolívar no haya dejado de "mirar con ojos condescendientes al pueblo". El futuro Libertador parte en realidad de una posición de desconfianza. La metamorfosis que va experimentando lo lleva a fundar y a defender un sistema político moderno en el cual deja de lado las distinciones del mundo colonial y de su clase en provecho de un entendimiento cabal de la sensibilidad popular, que intenta "incorporar a su repertorio de soluciones" y de virtudes republicanas divulgadas/enseñadas por quien corresponda, ambos puntos debidamente tratados en el recorrido discursivo que nos lleva de la Carta de Jamaica al Discurso de Angostura. El entendimiento de la autoridad por parte del héroe, el trasfondo constante de la mentalidad en la cual se formó es, por ende, otro punto clase de esta aproximación en términos de representaciones políticas y sociales. La autoridad la ejerció de hecho y sin trabas casi hasta el final de sus días. Por todas estas razones, el mismo Marx le tuvo poco aprecio a la figura y a la acción pública del Libertador. No dejó incluso de denunciar esta for-

5 Frédérique Langue: "Las ansias de vivir y las normas del querer. Amores y mala vida en Venezuela", en Elías Pino Iturrieta (coord.): Quimeras de amor, honra y pecado en el siglo XVIII venezolano, Caracas, Planeta, 1994, pp. 35-64; y Aristócratas, honor y subversión en la Venezuela del siglo XVIII, Prefacio de E. Pino Iturrieta. Caracas, Academia Nacional de la Historia, 2000 . 
ma renovada de despotismo y los afanes reeleccionistas, así como las ambiciones dictatoriales de Bolívar. ${ }^{6}$

\begin{abstract}
Revestido en el manto de unas constituciones de las que fue hábil redactor, no estimó cabalmente aspectos esenciales del ideario liberal, como la alternabilidad en el ejercicio de los cargos públicos o la beligerancia de los grupos de oposición sin los cuales era imposible la puesta en marcha una sociabilidad como la que proclamaban los papeles de la Independencia”. En los confines que estableció para la creación de una convivencia distinta de la colonial prevaleció la confianza hacia élites letradas y el exagerado encomio de unos hombres de armas que la final le dieron la espalda, pero a quienes mimó como hijos predilectos. ¿Fallas o pecados de un individuo que persigue el poder a todo trance? Apenas peculiaridades dominantes de quien sólo podía llegar hasta la meta marcada por las necesidades de un entorno convulsionado, por la diversidad de los territorios que quiso dominar y por una sociedad conducida a la ruina debido a una guerra en la cual las consideraciones humanitarias sólo se asomaron en las postrimerías.?
\end{abstract}

La figura del Libertador, su vida tanto pública como privada, despiertan constantemente interés y pasiones. La complejidad del personaje y del proceso que lideró, la dificultad que hay también en desvincular al hombre del mito constituyen un reto y una paradoja que llevaron a John Lynch a retomar la controvertida biografía de un Bolívar tan celebrado por los conservadores como por los marxistas. Apoyándose en fuentes primarias, no puede sino resaltar la relación ambigua que tuvo el Libertador, representante de la elite local, con la "pardocracia", parte de la naciente clase media americana para retomar un señalamiento de Manuel Pérez Vila, su alejamiento del modelo integrador francés o americano, hasta la determinación final de solventar la situación logrando alguno que otro equilibrio entre tiranía y anarquía (Constitución de Bolivia, 1826). La historia militar, por no decir las hazañas guerreras, ocupa aquí poco espacio en beneficio del contexto político y del espacio social y económico. Este tipo de publicación arroja además otra valiosa conclusión, aunque no siempre expresada con la debida firmeza: el imaginario democrático venezolano no se remonta a la época de la Independencia sino a un momento estructurante posterior, el de la "revolución de octubre". En el imaginario político nacional, el 18 de octubre de 1945 y el golpe de Estado encabezado por el general Medina Angarita, propiciado por los oficiales de la "Unión Patriótica

6 E. Pino, "Para un boceto..."; Inés Quintero y Vladimir Acosta: El Bolívar de Marx: Caracas, Editorial Alfa, 2007. Sobre los mestizos y otras poblaciones "de color quebrado" en la revolución, véase el excelente trabajo de Alejandro Gómez: "La Revolución de Caracas desde abajo", Nuevo Mundo Mundos Nuevos, n. ${ }^{\circ}$ 8-2008, http://nuevomundo.revues.org/index32982.html

7 E. Pino: "Para un boceto...". 
Militar", cobra especial relevancia. Finalizó sin embargo muy pronto con otro golpe militar, en contra del gobierno de Rómulo Betancourt, el 24 de noviembre de 1948. Junto al 23 de enero de 1958, otro símbolo del pueblo heroico y de la caída del gobierno dictatorial de Marcos Pérez Jiménez que le dio paso al pacto de Punto Fijo, la "gloriosa Revolución de octubre" descansaba en efecto sobre tres pilares: la construcción de identidades populares, la institución de una democracia "efectiva" (sufragio universal) y un nacionalismo económico. Como lo subrayó F.-X. Guerra, "la nación es en el mejor de los casos un proyecto: en la mayoría de los otros, un problema, jalonado por múltiples fracasos" que se evidencian en la desintegración de los espacios políticos americanos. ${ }^{8}$

\section{Los vericuetos de una historia oficial. Consideraciones previas}

La historia reciente o historia del tiempo presente nos lleva más que cualquier otro periodo a afrontar el tema de la "recepción del acontecimiento". Se considera tanto la manera cómo se escribe acerca de un hecho determinado como los ecos de un pasado considerado anteriormente como lejano, por no decir finalizado. Ahora bien, este pasado cuidadosamente albergado en las memorias colectivas o individuales resulta ser un instrumento imprescindible de comprensión del tiempo presente ante otros actores ocasionales pero no menos ofensivos cuando de escritura de la historia se trata (medios de comunicación, poder político y judicial). En este orden de ideas, hay que recordar que la epistemología mixta puesta de relieve por P. Ricœur para la disciplina histórica, entrelazamiento de objetividad y de subjetividad, se funda en un doble proceso de explicación y de comprensión de lo otro alejado en el tiempo, que se sustenta sin embargo en una discursividad propia y un vocabulario de hoy. ${ }^{9}$

8 John Lynch: Simón Bolívar. A Life, New Haven-London, Yale University Press, 2007. Frédérique Langue: "Les cendres des héros. Mémoires et histoires du temps présent vénézuélien”, en Luc Capdevila y Frédérique Langue (coords.): Entre mémoire collective et histoire officielle, Rennes, PUR, en prensa. Luis Ricardo Dávila: "Momentos fundacionales del imaginario democrático venezolano", en Guillermo Carrera Damas, Carole Leal Curiel, et alt: Mitos políticos en las sociedades andinas, Caracas, Ed. Equinoccio/IFEA/Université de Marne La Vallée, 2006, pp. 129-160. F.-X. Guerra, "La ruptura...", pp. 129-160.

9 Paul Ricœur: La mémoire, l'histoire, l'oubli, Paris, Seuil, 2000. P. Ricœur: "Objectivité et subjectivité en histoire", en Histoire et Vérité, Paris, Le Seuil, 1955, p. 30. F. Langue e D. Irwin (eds.), Militares y poder... Arlette Farge: Le cours ordinaire des choses dans la cité du XVIII siècle: Paris, Seuil, 1994, p. 19. Marc Ferro: Les individus face aux crises du XXe siècle. L'histoire anonyme, Paris, Editorial Odile Jacob-Histoire, 2005, véase prefacio. 
Ahora bien, rescatar a los olvidados de la historia gracias al doble prisma (de la recepción del acontecer histórico y las "representaciones"/ "sensibilidades") no lleva una historia de los anónimos, ni cuando de periodos confusos y conflictivos se trata, lo que es sin lugar a dudas el caso de la Revolución de Independencia en América. Tan sólo recordaremos el papel de la memoria en distintas escalas (individual, colectiva), en contra del olvido selectivo (uso de ciertas categorías: clases dominantes, historiografías oficiales etc.). Las palabras rescatadas en los documentos de archivo o en testimonios más recientes remiten a determinada configuración social, a situaciones de tensión donde las palabras llegan a resquebrajar el espacio social al declinar el conjunto de las coacciones y de los desgarramientos experimentados con motivo de "incidentes" vividos a diario, dentro del "curso ordinario de las cosas". ${ }^{10}$ Los conflictos/juicios posibilitan la presencia de los olvidados de la historia en los acervos históricos pero no desempeñan sino un papel de catalizadores en escalas muy diversas, puesto que irrumpe la palabra singular junto a la condición común de una historia impuesta y sufrida a la vez. ${ }^{11}$ Y más cuando el historiador presencia los hechos que estudia ("historia del tiempo presente"), situación desestabilizadora (se desconoce el final de la historia) que en no pocas oportunidades despierta por lo tanto la suspicacia conservadora del gremio historiador. ${ }^{12}$

Otra observación fundamental a la hora de compaginar estudio del tiempo presente (por no decir historia "inmediata" o de lo inmediato) y referencias a un pasado lejano aunque omnipresente en las memorias: ubicarse en la perspectiva de las sensibilidades y de las representaciones que las sustentan requiere un balance previo. Gran parte de la historiografía americanista en ese campo sigue siendo, en este aspecto, un avatar de la historia de las mentalidades, dominada por una historia de las elites, o "clases dominantes de la sociedad indiana", que tiene mucho que ver con las fuentes disponibles (producidas efectivamente por una elite política y cultural), especialmente para el periodo colonial y las primeras décadas del siglo XIX.13

10 Farge, A.: Le cours ordinaire des choses..., p. 9.

11 Jacques Revel (dir.): Jeux d'échelles. La micro-analyse à l'expérience, Paris, Hautes Etudes/Gallimard/Le Seuil, 1996.

12 Frédérique Langue: Hugo Chávez et le Venezuela. Une action politique au pays de Bolívar, Paris, L'Harmattan, 2002.

13 Frédérique Langue: “¿Estrategas o patriarcas? La aristocracia empresarial zacatecana a fines del siglo XVIII-principios del XIX”, en B. Schröter y C. Büschges (eds.): Beneméritos, aristócratas y empresarios. Identidades y estructuras sociales de las capas altas urbanas en América hispánica, Madrid-Frankfurt, Vervuert-Iberoamericana, 1999, pp. 277-295. 
Los siglos posteriores multiplican las fuentes, a veces de forma excesiva, en su vertiente virtual y dentro de un contexto globalizado que tiende a difuminar la recepción misma del acontecimiento, por más ínfimo que sea, y le confiere "actualidad" en el sentido de Foucault, al demultiplicar las interpretaciones y reacciones. El mayor escollo radica por lo tanto en la selección y crítica de las fuentes. De ahí la acepción de la historia de las sensibilidades en cuanto "recepción del acontecimiento", aunque resulten ser "de escasa intensidad", y de los sentimientos y pasiones que de ello se derivan. Por muy precisos que sean, los trabajos de historia social no suelen contemplar estas expresiones en el orden emocional, por seguir unos lineamientos centrados en hechos de rebelión y resistencia y hasta de resilience. ${ }^{14}$ En este sentido, la historia de las sensibilidades relativiza estas aproximaciones, al remitirnos constantemente a las circunstancias de su elaboración y a las representaciones sociales que las anteceden, y por eso mismo se ubica arriba de la llamada "historia de las emociones": "El historiador tiene como tarea la de facilitar un conocimiento adecuado de aquel "pueblo de los desaparecidos". Abandonar esta pretensión, quizás desmedida aunque no menos fundadora, consistiría en dejarle el campo libre a cualquier falsificación intencional de los hechos ocurridos y a la aceptación de una historia

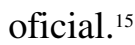

Entre estos acontecimientos catalizadores de pasiones inéditas o inesperadas, conviene sin lugar a dudas incluir las palabras mismas. Muchas batallas, efectivas o figuradas, como puede ser el caso en el orden político o ideológico, son en primer lugar batallas de palabras e ideas. Reductoras o forjadoras de sentido, en adelante las palabras expresan una construcción cultural y política encaminada hacia la formulación de una "historia oficial". En semejante contienda, sólo el preciso conocimiento del pasado permite escudriñar el presente, vislumbrar y contrarrestar negaciones del pasado o ejemplificar rupturas verdaderas dentro de un proceso histórico. ${ }^{16}$ Allí cunde la imprescindible conexión entre historia y memoria, tal como lo puso de relieve Georges Duby. Fuera de las memorias y de una conciencia

14 Véanse los estudios propiciados por el Centro Nacional de Historia http:// www.cenhisto.gob.ve/

15 Arlette Farge: Quel bruit ferons-nous? Entretiens avec Jean-Christophe Marti, Paris, Les Prairies Ordinaires, 2005. Frédérique Langue: "O sussurro do tempo. Ensaios sobre uma história cruzada das sensibilidades Brasil-França”, en Marina Ertzogue y Temis Parente (coords.): História e sensibilidade, Brasilia, Paralelo 15, 2006, pp. 21-32.

16 Arlette Farge y Michel Chaumont: Les mots pour résister. Voyage de notre vocabulaire politique de la Résistance à nos jours, Paris, Bayard, 2005, p. 11. 
colectiva, el acontecimiento deja de existir como tal, está ligado estrechamente al flujo y reflujo de la memoria y del olvido. De ahí el hecho de que una investigación de tipo historiográfico no pueda hacer caso omiso del análisis pormenorizado de las construcciones simbólicas. ${ }^{17}$ No por eso se trata solamente de inventariar pasiones olvidadas y de rescatar a actores sociales descartados por la historia académica, sino de contrarrestar historias oficiales en un contexto movedizo de globalización de la información y de las ideas. Otro punto que merece ser subrayado es la "fábrica social" de la historia como ciencia y consciencia, la ubicación del relato histórico en una configuración peculiar que no hace caso omiso de las emociones afines. El análisis del acontecer histórico coincide nuevamente con la experiencia de los actores: "la mayoría de la gente no vive en la Historia, en la actualidad. En realidad viven su vida. Tal es la historia anónima, la de la gente de la calle". ${ }^{18}$ Estos deslices de la perspectiva se ubican desde luego en un determinado acercamiento metodológico, junto a una imprescindible lucidez crítica que rescata "la traza de estas acciones y el juego de estas conmemoraciones" en el tiempo, no el pasado tal como ocurrió sino la manera como se constituyó y se transmitió en cuanto objeto histórico y parte del imaginario de una nación. ${ }^{19}$

El caso ejemplar de Bolívar, figura mítica objeto de numerosas interpretaciones historiográficas, es el de una persona omnipresente, tanto en la propia Venezuela como en el exterior, y en el tiempo largo. Es el héroe redentor, precursor del panamericanismo y defensor del ideario liberal durante la Revolución de Independencia. Fue precisamente esta "heroarquía" (en cuanto repertorio heroico de la "historia patria"), para retomar el término de Thomas Carlyle, el destacado exponente de la teoría del héroe (desde el año 1843), la que sirvió de andamio a Venezuela para construirse como nación. Se convirtió en una referencia identitaria obligada para el Estado venezolano en las postrimerías del siglo XIX, a partir de la repatria-

17 Georges Duby: Le Dimanche de Bouvines, Paris, Gallimard, 1973. Pierre Joutard: "L'histoire orale entre science et conscience", Vingtième siècle Revue d'histoire, n. ' 25, Paris, janviermars 1990.

18 M. Ferro: Les individus face aux crises $d u X X^{e}$ siècle... Frédérique Langue: "L'histoire des sensibilités. Non-dit, mal dire ou envers de l'histoire? Regards croisés France-Amérique latine", Nuevo Mundo Mundos Nuevos, Número 6 - 2006, http://nuevomundo.revues.org/document2031.html. Monográfico de la revista Terrain, n. ${ }^{\circ}$ 38, Paris, mars 2002, "Qu'est-ce qu'un événement?", y en esta entrega, el artículo de Arlette Farge, "Penser et définir l'événement en histoire", disponible en: http://terrain.revues.org/

19 Pierre Nora: Les lieux de mémoire, Paris, Gallimard, 1993, t. 3, vol. 1, p. 24. 
ción de sus restos en 1842 y luego, durante el gobierno positivista de Guzmán Blanco, con la celebración del natalicio del Libertador. El matiz conservador del ideario bolivariano es, sin embargo, el aspecto que más se busca en ese momento. Hasta se trasladó a Europa, con un sesgo algo antiparlamentarista que los doctrinarios del fascismo italiano no dejarán de recordar; es el cesarismo de corte bonapartista. Sin embargo, las dos vertientes del personaje volvieron a aparecer después de la "guerra fría", es el "héroe para todas las causas", incluso las causas utópicas (véase. Miguel Acosta Saignes): héroe libertador defensor de la libertad para unos, precursor de la guerra libertadora y hasta del antiimperialismo para otros. La religión cívica del bolivarianismo y el "museo itinerante" (P. Calzadilla) de los objetos o símbolos que conlleva, recoge por lo tanto el mito oficial del Libertador como otra imagen, mucho más radical, del revolucionario que hubiera sido en lo social. De tal forma que, al posibilitar un consenso en torno a los valores patrios en varios momentos de la historia nacional, Bolívar sigue siendo el garante o, cuando menos, el símbolo del orden establecido. ${ }^{20}$

Ahí radica una pregunta acerca de la historia oficial, junto al tema de las hagiografías nacionales, del olvido voluntario o de la anamnesia ejemplificada por Paul Ricœur, así como del estatuto del historiador. ¿Puede éste permanecer indiferente o incólume ante determinados hechos recordados o procesos actuales? De ahí la importancia del contexto a la hora de arrojar interpretaciones, a veces muy distintas, de un mismo acontecer, ya sea oficiales, políticas, colectivas, o bien particulares, individuales, partidistas etc. La omnipresencia del culto bolivariano, la arraigada posición del mito afín en el imaginario político venezolano, así como los ecos de carácter continental que encuentra no remiten sino a trazas memoriales de la gesta bolivariana. ${ }^{21}$ Hay aconteceres que, por motivos muy diversos, terminan silenciados u ocultados: el horror, el sentimiento de culpa o de impotencia, o la elección de cierta forma de hacer historia — caso de la historia

20 Thomas Carlyle: De los héroes, México, Cumbre, 1978. Pedro Enrique Calzadilla: "Las ceremonias bolivarianas y la determinación de los objetos de la memoria nacional en Venezuela", Tierra Firme, vol. 22, núm. 86, Caracas, 2004. Nikita Harwich Vallenilla: "Un héroe para todas las causas. Bolívar en la historiografía”, Iberoamericana, III-10, Madrid, 2003, pp. 7-22. María E. del Valle de Villalba: "El culto al héroe en la enseñanza de la historia: Germán Carrera Damas", Letralia, XI-n. ${ }^{\circ}$ 158, http://www.letralia.com. Miguel Acosta Saignes: Acción y utopía del hombre de las dificultades, La Habana, Casa de las Américas, 1977.

21 Pierre Nora: "Le retour de l'événement", en Pierre Nora y Jacques Le Goff (dir.): Faire de l'histoire. Nouveaux problèmes, Paris, Gallimard, 1974, pp. 210-228. 
oficial - fundada en una práctica de tipo ideológico. Algunos temas son, por definición, subversivos, o se convierten en tabúes, y "estos silencios no son olvidos ni prohibiciones". Identificar los tabúes posibilita el acceso al no-dicho de una sociedad, a través del modo de producción de relatos históricos que destierran las preguntas que molestan, exorcizan el pasado exaltando a la inversa otros momentos del mismo, o hacen hincapié en una mitología (caso de la llamada historia republicana en el continente latinoamericano) ocasionalmente compaginada con otro "ingrediente" sumamente descalificador, el resentimiento..$^{22}$

A lo largo de estos últimos años, y en relación con la conformación de una historia oficial y de un nuevo credo revolucionario, la nueva historia de Venezuela tendió a desvirtuar el "culto a Bolívar" tan preciado de los gobernantes criollos. Ese culto al héroe de la Independencia, portavoz del ideario de la emancipación en un nivel continental, culto sumamente movilizador, por y para el pueblo, suerte de religión cívica fundadora de una identidad nacional, siempre ha sido utilizado por los distintos gobiernos republicanos. El interés de la reescritura actual de la historia por el mismo presidente Chávez radica en el hecho de que Bolívar ya no es el aristócrata blanco (mantuano) o el defensor del orden que resultó ser hasta para ciertos autores europeos. Según varios defensores del régimen, hasta se convirtió en un mestizo, más precisamente en un zambo. De la revolución redentora ya se sabe que trae a colación muchas referencias históricas, esto desde los orígenes del movimiento bolivariano en los años 80 del siglo pasado (véase el "árbol de las tres raíces" o sea Simón Bolívar, Simón Rodríguez y Ezequiel Zamora). De hecho, resulta sumamente inestable la síntesis lograda por el Estado entre el culto heroico y la celebración del revolucionario social, cual mito de Sísifo, a semejanza de otras míticas construcciones identitarias latinoamericanas (Martí, Lautaro...). Implica por eso mismo una revisión radical de los símbolos patrios que nutren el imaginario social y el discurso revolucionario de ruptura con un pasado reciente (la IV ${ }^{a}$ República o "antiguo régimen").

El otro se convierte en el enemigo, su aniquilación se convierte en mandato. El pueblo organizado y formado en la ideología bolivariana se organizará en un primer momento en los "círculos bolivarianos", que tienen antecedentes en las "cívicas bolivarianas" durante el gobierno de López Contreras, en cuanto organizaciones sociales leales al régimen

22 Marc Ferro: Le ressentiment dans l'histoire... 
(1940). En este caso preciso, la violencia tiende a desplazar a la política como medio de dirimir diferencias. Se oficializó la referencia a los indígenas, que en adelante aparecen allí junto con un arco y una canoa; el caballo de los escudos nacionales, otrora "no venezolano" y "caballo del imperio" (español), en los términos del presidente Chávez en su emisión dominical Aló Presidente, mira en adelante hacia la izquierda. De ahí la polémica y hasta el acérrimo debate que surgió a fines del año 2005 y la movilización de historiadores de ambos bandos, incluyendo la Academia Nacional de la Historia, a favor de la "cohesión nacional" y en contra de la "Revolución de San Simón", o sea del uso de la historia por el poder y de fetiches ideológicos. Mientras que el artículo $1^{\text {ro }}$ de la Carta Magna reza: "La República Bolivariana de Venezuela es irrevocablemente libre e independiente y fundamenta su patrimonio moral y sus valores de libertad, justicia y paz internacional en la doctrina de Simón Bolívar, el Libertador". 23

"Contar ya es explicar", recordó Paul Ricœur. En este sentido, la historia de las sensibilidades hace uso de fuentes muy diversas, incluyendo fuentes orales, y en especial la memoria oral, que llega incluso a compen-

23 Marc Ferro: Les tabous de l'histoire, Paris, Nil Editions, 2002, pp. 33-34. Elías Pino Iturrieta: "La historia oficial", El Universal, 27 de octubre de 2003; El Universal y El Nuevo Herald, 8 de marzo de 2006; y El Universal, 28 de noviembre de 2005. Germán Carrera Damas: El culto a Bolivar, Caracas, Grijalbo, 1989, y Alternativas ideológicas en América Latina contemporánea (El caso de Venezuela: el bolivarianismo-militarismo), Gainesville, University of Florida-Universidad Central de Venezuela, 2001. Alejandro Gómez: "El papel de los intelectuales en la Venezuela de Hugo Chávez: los historiadores a la palestra pública", L'Ordinaire Latino-Américain, n. ${ }^{\circ} 202$, Toulouse, octobre-décembre 2005, pp. 83-94. Jorge Rueda: "Chávez impulsa cambios de símbolos patrios”, El Nuevo Herald, 20 de enero de 2006. Gerardo Blyde: "Batalla de símbolos", El Universal, 23 de junio de 2004 y "Bolívar, mantuano Libertador", El Universal, 10 de marzo de 2006. Frédérique Langue: "Mestizaje y redención en Venezuela. De las milicias coloniales a la Revolución Bolivariana", en Domingo Irwin, Hernán Castillo y Frédérique Langue (coords): Pretorianismo venezolano del siglo XXI. Ensayo sobre las relaciones civiles y militares venezolanas, Caracas, Universidad Católica Andrés Bello, 2007, pp. 259-299; y Hugo Chávez..., pp. cits., cap. IV. Academia Nacional de la Historia, comunicados de prensa del 23 de febrero y 3 de marzo de 2006: http://www.anhvenezuela.org/doctrina.php?id=11 John M. Kirk: "From "Inadaptado Sublime" to "Lider Revolucionario": Some Further Thoughts on the Presentation of Jose Marti", Latin American Research Review, Vol. 15, núm. 3, 1980, pp. 127-147. Elena Plaza: "Historiografía y nacionalidad: el Resumen de la historia de Venezuela de Rafael María Baralt", Tiempo y Espacio, vol. VII, núm. 13, Caracas, 1990, pp. 63-96. Mireya Lozada: "El otro es el enemigo. Imaginarios sociales y polarización", Revista Venezolana de Economía y Ciencias Sociales, n. ${ }^{\circ}$ 10-2, Caracas, 2004, pp. 195-209. Jaime Valdivieso: "El mito de Sísifo y su significado en el mundo actual: los mitos en Latinoamérica", Atenea, n. ${ }^{4}$ 487, Santiago de Chile, 2003, pp. 135-143. Nelly Arenas y Luis Gómez Calcaño: "Los círculos bolivarianos; el mito de la unidad del pueblo", América Latina Hoy, vol. 39, Salamanca, 2005, pp. 167-193. Elías Pino Iturrieta: "La Revolución de San Simón”, Letras Libres, México, julio de 2005 http://www.letraslibres.com 
sar los silencios de la historiografía y los tabúes vigentes (véase el ejemplo de la guerra del Chaco, especialmente en el caso paraguayo) que excluyen temas "subversivos" como la guerra, el mestizaje o el nacionalismo. ${ }^{24}$ En el caso del mito bolivariano, la memoria no se contrapone al olvido, por ser la memoria de los aludidos una interacción de ambos fenómenos ( $\mathrm{T}$. Todorov). Para el historiador, resulta ser en cambio una memoria fragmentada, que entorpece la reescritura de una historia nacional, al favorecer una historia oficial y, posiblemente, manipulaciones del pasado. En este sentido, el mito bolivariano no es una mera museografía alejada del presente. ${ }^{25}$ Cualquier discurso acerca de un acontecimiento reciente connotará por lo tanto hechos anteriores en la trama discursiva, en una suerte de tramoya interpretativa que les confiere sentido. El tiempo ya no es único y lineal sino que pluraliza los modos de racionalidad del mismo. ${ }^{26}$

A la consagrada "historia oficial" se le contrapone por consiguiente la "libertad del historiador", planteándose el problema de la transmisión de la historia. Resulta por lo tanto pertinente rechazar la confusión, tan frecuente en los medios de comunicación, entre memoria e historia. El caso de la esclavitud, de la colonización (en varios contextos, como lo demostró el caso francés), ponen de relieve esta confusión entre una memoria legítima que recoge sufrimientos del pasado y la escritura de la historia. La memoria bolivariana, tal como asoma en los discursos de Hugo Chávez, se ve confortada por cualquier detalle o anécdota, a diferencia de las interpretaciones siempre relativas que propone la historia. En el primer caso impera la creencia y cualquier cuestionamiento puede equipararse con un sacrilegio. Tiene como consecuencia un mecanismo de exclusión: en este caso preciso, uno está a favor de la Revolución o está en contra, no hay término medio. La memoria es sagrada y alcanza el registro de las emociones. En este sentido, el trabajo pacificador del historiador se opone al quehacer del político, del legislador o del juez en la medida en que los conflictos recor-

24 Paul Ricoeur: Temps et Récit, Paris, Le Seuil, 1985, tome 1, reed. Points-Seuil, 1991, p. 251. Sobre el Paraguay, remitimos a las ponencias del Coloquio Internacional "El Paraguay a la sombra de sus guerras" (noviembre de 2005), publicadas en Nuevo Mundo Mundos Nuevos n. ${ }^{\circ}$, 2006 http://nuevomundo.revues.org

25 Luc Capdevila: "Mémoire de guerre", Le temps des savoirs, n. . 6, 2003, p. 70. y "Les temporalités de l'événement”, pp. 79-89. Tzvetan Todorov: Les abus de la mémoire, Paris, Arléa, 1995, p. 14.

26 Reinhart Koselleck: Le futur passé. Contribution à la sémantique des temps historique, Paris, EHESS, 1990. Pierre Nora: “De l'histoire contemporaine au présent historique”, en Ecrire l'histoire du temps présent, Paris, IHTP, 1993, p. 45. 
dados no hacen sino evidenciar las dificultades de los países en asumir su propio pasado. ${ }^{27}$

El ejemplo de la República Bolivariana de Venezuela pone de relieve el carácter sumamente conflictivo de lo que se puede ejemplificar como "memorias paralelas", hasta en presencia de un mito unificador de la nación. Mientras la historia une, la memoria tiende a dividir, como lo indicaría en el caso de España el controvertido traslado de parte del Archivo General de la Guerra Civil, conservado en Salamanca, a la Generalitat de Cataluña. ${ }^{28}$

Estas consideraciones evidencian el hecho de que el pasado puede ir cobrando sentidos nuevos e inéditos con el transcurrir del tiempo. El régimen de las temporalidades sucesivas tiende de esta manera a rescatar a un sinfín de actores sociales olvidados de la historia oficial y del sistema de representaciones sociales y políticas que conlleva. Estas observaciones, que también son válidas para otros países, tienen especial importancia en el caso latinoamericano habida cuenta de la "intrusión" de lo político en la historia. Bien se conoce al respecto el tema de las historias oficiales, y basta con reportarse a la espléndida película de Luis Puenzo (Argentina, 1985) para comprobarlo. En el caso venezolano, también varias películas y varios productores (incluyendo a estadounidenses como por ejemplo el director Oliver Stone, ardiente defensor del presidente Chávez, a cubanos e iraníes, o a mexicanos como Francisco Taboada, contratado por el propio Chávez) buscan ofrecer "otra" visión alternativa de la historia nacional (véase la rehabilitación de Miranda y el largometraje de Diego Rísquez, "Francisco de Miranda" (Venezuela, 2006)), para mencionar una realización ajena al propósito ideológico que encubren filmaciones "bien intencionadas" como La Revolución no será transmitida, documental realizado por cineastas irlandesas acerca de los "sucesos de abril" (2002) o abiertamente militantes, y sus declinaciones ulteriores en los dos bandos (i.e. para el bando opositor ¿Cuál Revolución? Hugo Chávez 1999-2004 -de 2005- o La lista, de 2006, junto a ¿Venezuela se uniforma? y El único soy yo, ambas de 2007), hasta en una vertiente romántica que,

27 Editorial y artículos publicados en Le Monde: "Peut-on comparer les traites? L"'affaire Pétré-Grenouilleau", 9 de enero de 2006 ; Jérôme Gautheret: "Traites négrières, esclavage: les faits historiques", 9 de enero de 2006.

28 Una cronología de los hechos en: http://web.aytosalamanca.es/archivo/index.html, El Mundo; "Los "papeles de Salamanca": del franquismo a la actualidad", 31 de enero de 2006, http://ariadna.elmundo.es; El País, 26 de enero de 2006 (http://www.elpais.es/). 
sin embargo, logra restituir episodios como el Caracazo (Román Chalbaud, 2005)..$^{29}$

Sólo una lectura que vaya más allá de los aconteceres puntuales y contemple la aprehensión de las sensibilidades evidenciadas en esa oportunidad ofrece una mirada global, que pueda precisar un proceso histórico aún vigente, así como sus implicaciones en un marco ideológico contrastado y exacerbado. Sensibilidades manifiestas asoman en el caso venezolano, a través del discurso pero también de la verdadera "guerra de las imágenes" protagonizada por los medios de comunicación o el cine, junto a la apropiación de mitos continentales (Bolívar, el Che) por la historia oficial y a la frecuencia de las conmemoraciones de cuño histórico, aunque con visos maniqueístas: Santa Inés (10 de diciembre de 1859, una de las acciones militares más importantes de la Guerra Federal, la ganó el "general del pueblo soberano" Ezequiel Zamora, una de las principales referencias históricas del presidente Chávez) durante la campaña electoral previa al referendum de agosto de 2004; Día de la Resistencia Indígena para el 12 de octubre: a los 500 años de la llegada de Cristóbal Colón, esta celebración se volvió a bautizar mientras se destruyó la estatua de Colón en Caracas); la creación de un "comando Maisanta" (caudillo rebelde, bisabuelo del presidente) para llevar la campaña electoral y mediática del año 2004. Los días festivos relacionados con la "primera Independencia" y el nacimiento de una conciencia nacional (el fundacional 19 de abril de 1810 con la firma del acta de Independencia; 5 de julio de 1811, Día de la Independencia; 24 de julio, natalicio de S. Bolívar) sólo dieron lugar a desfiles militares. En vísperas de las elecciones presidenciales de diciembre de 2006, fue el amor el protagonista mayor de la campaña: "por amor a Venezuela" rezaban los afiches del presidente a punto de reelegirse, con tonos azules bastantes suaves que contrastaban con el "rojo-rojito" de los años anteriores. En los años 2007-2008 y la afirmación no sólo de la "Revolución bolivariana" sino del "socialismo del siglo XXI", regresaron las boinas rojas al escenario mediático y callejero, junto a los retratos de S. Bolívar y de H. Chávez. ${ }^{30}$

29 Alejandro E. Gómez: "Las aventuras de Francisco de Munchausen”, Nuevo Mundo Mundos Nuevos, n. ${ }^{\circ}$ 7, 2007, http://nuevomundo.revues.org/index3920.html Frédérique Langue: "El Caracazo", Nuevo Mundo Mundos Nuevos, n. ${ }^{\circ}$ 6, 2006, http://nuevomundo.revues.org/index2700.html.

30 Sobre la batalla de Santa Inés y su alcance para los "revolucionarios de hoy", véase el sitio chavista http://www.aporrea.org/ Y sobre el 19 de abril, el sugestivo artículo de Carole Leal Curiel: "El 19 de abril de 1810: la "mascarada de Fernando" como fecha fundacional de la Independencia de Venezuela", G. Carrera Damas; C. Leal Curiel et alt., Mitos políticos en las sociedades andinas..., pp. 65 y ss. 
FRÉDÉRIQUE LANGUE

\section{¿El bolivarianismo, religión “cívica” o religión "republicana”?}

Ahora bien, la reliquia quizás más preciada de la Revolución bolivariana y de la mitología oficial al respecto sigue siendo la espada de Bolívar, símbolo desde la Revolución de Independencia de la identidad nacional y regional en el imaginario político y también en los textos fundadores del Movimiento bolivariano y, como tal, reivindicado por movimientos de guerrillas colombianos desde los años 1970 (y "raptado" de un museo bogotano por el M-19). Este "fetiche republicano", que no es sólo un objeto de obligada conservación en ese museo o de réplicas que se les obsequian a los visitantes extranjeros de alto rango, invocado con frecuencia por un líder carismático y (neo) populista se inserta en un conjunto de referencias y un imaginario revolucionarios que van mucho más allá de las fronteras nacionales. Los mismos propósitos del "proceso" —la Revolución bolivariana para sus seguidores - se extienden al continente en su conjunto (véanse el proyecto del ALBA, Alternativa Bolivariana para las Américas, para contrarrestar la influencia norteamericana en lo económico, o varios programas de solidaridad y cooperación). Libertadora de las Américas, la espada de Bolívar se convirtió en uno de los lemas de los partidarios de la Revolución "continental", movimientos alter mundialistas incluidos. De esta forma se evidenciaría otra faceta del culto a Bolívar tal como lo analizó Germán Carrera Damas, y que este historiador no vacila en calificar de bolivarianismo-militarismo. El desarrollo del culto a Bolívar en su nueva versión sugiere sin embargo la posibilidad de que no se contenga en los confines nacionales. A partir del año 2002, es frecuente que el presidente y sus seguidores concluyan las arengas con la siguiente consigna: "¡Alerta, alerta, que camina la espada de Bolívar por América Latina! ¡Bolívar vive, la lucha sigue!”. En junio del 2001 se empiezan a promover los Círculos Bolivarianos, para sostener el proceso revolucionario en Venezuela y con la única advertencia de que para pertenecer a ellos "sólo se necesita compartir la doctrina bolivariana", confortando una vez más, según unos estudiosos del tema, el "mito de la unidad del pueblo" y la permanencia de ese pasado idealizado (aunque no exento de violencia, al igual que muchas construcciones míticas), casi intemporal y, en todo caso, patriótico, nacionalista y latinoamericanista/continental, que nunca llega a ser pasado en el sentido estricto de la palabra (véase al respecto la frase de Neruda: "Bolívar revive cada cien años, cada 
vez que los pueblos se despiertan", muy a menudo citada por Hugo Chávez en sus discursos. ${ }^{31}$

El empeño de Chávez en presentarse como el Bolívar del siglo XXI obedece sin lugar a dudas a un profundo conocimiento del pensamiento bolivariano, pero también al carácter atractivo del personaje histórico, héroe que, a fin de cuentas, despierta sentimientos positivos en la sociedad venezolana y sólo produce unanimidad. A estas circunstancias se les une el hecho de que Bolívar siempre ha sido el patrón predilecto de los militares. En resumidas cuentas, son escasas las semejanzas con el héroe. En cambio, sí se han subrayado los parecidos entre el presidente Chávez y José Tadeo Monagas (presidente entre los años 1847-1858). Como puso de relieve E. Pino Iturrieta en una entrevista, Monagas se empeñó en reformar la Constitución para mantenerse en el poder. Con Chávez, en 1999 tuvo lugar un primer cambio constitucional (Constitución Bolivariana) y una revisión formal se está llevando a cabo actualmente, con el fin, entre otros propósitos, de permitir la reelección indefinida del mandatario. El PSUV (Partido Unificado Socialista de Venezuela), está en vías de constitución, sustituyendo al electoralista Movimiento Quinta República, heredero del movimiento bolivariano clandestino creado en los cuarteles en los años 1980 (a semejanza de otras logias militares). En el caso de Monagas, se alejó de los partidos de aquel entonces para sustituirlos por un círculo de amigos y familiares, llegó a controlar todos los poderes del Estado y pregonó la doctrina bolivariana hasta en lo que a integración continental se refiere. Monagas sería, en la historia de Venezuela, la "primera expresión redonda del personalismo venezolano y Chávez representa el personalismo de turno". Una pregunta afín sería ¿Cómo puede una revolución que se haga llamar bolivariana ser — a la vez — socialista? Un repaso por los escritos de Marx mostraría el escaso apego del filósofo a la figura del Libertador y la valoración más bien negativa que aquel tuvo de Bolívar,

31 Alejandro Gómez: "La reliquia más preciada de la Revolución bolivariana", en Domingo Irwin G. y Frédérique Langue (coords.), Militares y poder en Venezuela...., pp. 179-203. Análisis del pensamiento bolivariano en sus distintas vertientes interpretativas en el número especial de Tiempo y Espacio, n. ${ }^{\circ}$ 34, Caracas, 2000. G. Carrera Damas: Alternativas ideológicas en América Latina contemporánea... María Elena González Deluca: "Historia, usos, mitos, demonios y magia revolucionaria", Revista Venezolana de Economía y Ciencias Sociales, vol. 11, n. ${ }^{\circ}$ 2, Caracas, 2005, pp. 159-186. http://revele.com.ve//pdf/revista_venezolana_de_economia_y_ciencias_sociales/vol11-n2/pag159.pdf Nelly Arenas y Luis Gómez Calcaño: "Los Círculos Bolivarianos: el mito de la unidad del pueblo" (artículo publicado anteriormente en la revista América Hoy), en N. Arenas y L. Gómez Calcaño: Populismo autoritario: Venezuela 1999-2005, Caracas, CENDES/CDCH-UCV, 2006, pp. 97-128. 
aunque siempre ha habido en la historia de Venezuela un uso arbitrario del discurso de Bolívar, que lo descontextualiza con fines políticos. ${ }^{32}$

El historiador, crítico y ex diplomático Germán Carrera Damas, autor del estudio más relevante acerca del culto a Bolívar, ya citado, llegó a esbozar un cuadro mucho más despiadado del "permanente culto al Héroe nacional-Padre de la Patria" (esta condición le fue reconocida a Bolívar junto a la de fundador de la Gran Colombia en 1823), y de la "sumisión recurrente al Anti-héroe nacional — padrote de la Patria — (habida cuenta del manejo discrecional y autoritario del poder por los gobernantes), junto a un "desorbitado y manipulador culto heroico". Para G. Carrera Damas, el entonces "Anti-héroe nacional-padrote de la Patria", si bien nos remite a la república liberal autocrática y a la cuestionable "dictadura comisoria" de Bolívar en 1828, es

un arquetipo del despotismo, obtenido con desiguales aportes, pero con idéntica disposición de engendrar sucesor, mediante la destilación de la personalidad y obra de los generales Antonio Guzmán Blanco, Cipriano Castro, Juan Vicente Gómez, Eleazar López Contreras, Isaías Medina Angarita y Marcos Pérez Jiménez, con el añadido actual del teniente coronel golpista sobreseído Hugo Chávez Frías, y establecido por la tradición como Némesis de las aspiraciones democráticas de la sociedad venezolana, presentes desde 1863.

La conexión entre ambos, el héroe y el anti-héroe, ha consistido, según este autor, en que el primero ha sido utilizado constantemente como fuente de legitimación ideológica y de "aval político", del segundo, sin que se hubiese expresado claramente la conveniencia de un presidente con derecho a designar su sucesor, en una suerte de híbrido de Monarquía constitucional. Y la literatura se prestó a esta exaltación del heroísmo militar abono del caudillismo a lo largo de la historia nacional, so capa de patriotismo (véase Larrazábal). ${ }^{33}$ Pese a que la guerra de independencia fuera una guerra civil (de acuerdo con Laureano Vallenilla Lanz y su Cesarismo

32 Elías Pino Iturrieta: "Los mitos políticos se gastan" y Nada sino un hombre. Lourdes Molero de Cabeza: "El personalismo en el discurso político venezolano. Un enfoque semántico y pragmático", Espacio Abierto, v. 11, núm. 2, Maracaibo, 2002 (disponible en Scielo Venezuela). I. Quintero y V. Acosta: El Bolívar de Marx...

33 Germán Carrera Damas: "Entre el héroe nacional-padre de la Patria y el anti-héroe nacional-padrote de la patria", Arbor Ciencia-Pensamiento y cultura, CLXXXIII-724, Madrid, marzo-abril, 2007, pp. 203-210. Reproducido en: http://www.saber.ula.ve/db/ssaber/Edocs/pubelectronicas/procesoshistoricos/vol5num10/documento1.pdf y http://www.aladecuervo.net/logogrifo/0502/sem4/conciencia_nacional.htm 
democrático, 1919), Bolívar siempre contempló la necesidad de ajustar las instituciones a esa suerte de propensión de la sociedad hispano-americana hacia la disgregación. De ahí que su visión política, especialmente en la última etapa de su vida, favoreció un poder ejecutivo de corte cesarista, pero siempre republicano. Estas circunstancias dejaron sin fundamento la "tentación monárquica" que se le había achacado.

Con el ejemplo de Venezuela se comprueba sin embargo que, aunque un partido o un gobernante logren apoderarse de símbolos, de lugares, de ideas, de personajes históricos sobredimensionados — convirtiendo al mantuano Bolívar en un adalid popular, disfrazándolo a veces de mestizo- y hasta de leyendas y mitos diversos, de ninguna manera los actores y creadores de la nueva historia oficial pueden adueñarse de las sensibilidades. Las prolongan en parte, convergen con ellas, o se le oponen. Estas "reacciones epidérmicas", en pro o en contra, que afloran en la opinión pública venezolana de hoy, quizás no sean más que una respuesta a una serie de acontecimientos que participan por cierto de una memoria colectiva en el tiempo largo, así como de una experiencia vivencial más delimitada a nivel relacional (comunidad, partido, relaciones personales o familiares, nexos entre individuos) y más todavía cuando un líder carismático como Hugo Chávez, portavoz de una suerte de populismo revolucionario, se ubica en tal grado en el registro emocional e incluso afectivo. La liturgia creada alrededor del Libertador se funda en la repetición hasta la saciedad de citas de Bolívar, gracias a la excelente memoria del presidente, y en una exaltación mesiánica del Libertador. El problema radicaría, si seguimos los señalamientos de E. Pino, en la utilización de referencias fragmentarias desconectadas del contexto inicial y en el peligro de anacronismo que conlleva: "suele utilizar los textos bolivarianos para arrimar la brasa a su sardina". El pensamiento de Bolívar no deja de tener vigencia, al ser parte de una lucha por la justicia social, por el bienestar de las mayorías, por la soberanía de las naciones latinoamericanas y la unidad continental, pero es imprescindible recordar que fue expresión de su tiempo. Habría que mencionar de nuevo a otra figura omnipresente en el discurso presidencial, la de Maisanta, "general del pueblo soberano" en el siglo XIX (véase la obra de F. Brito Figueroa) y para otros historiadores,

... guerrillero más bien opaco que gozó de fama en los medios rurales durante el gomecismo, uno de tantos en el enjambre de campesinos pasados por la molienda de la dictadura. Un personaje pintoresco que puede caber con comodidad en el espacio 
de las crónicas parroquiales, pero quien ascendió al olimpo nacional por el amoroso frenesí de su nieto. ${ }^{34}$

\section{Ideario político y tentación personalista sui generis}

En este sentido, la historia reciente de Venezuela constituye un verdadero laboratorio para el historiador, tanto a escala del país mismo, como del continente, por más que la información al respecto no siempre quede desligada de intenciones políticas e intente sustituir a las sensibilidades iniciales en su diversidad por una seudo-conciencia histórica/bolivariana y una retórica unificada en provecho exclusivo de un "lenguaje al revés" que convierte al presidente en mesías. Resulta imprescindible en este aspecto analizar el propio liderazgo de H. Chávez, en cuanto sustituto y redentor de un país pasado por la IV República puntofijista. El presidente se ha convertido en efecto en el jefe de Estado venezolano con más poder personal, tanto factual como carismático, desde los tiempos del "tirano liberal" Juan Vicente Gómez (1908-1935), esto además en un país de fuerte tradición presidencialista. Importa aquí este tipo de liderazgo, tanto a nivel de la alianza partidista que lo apoyó con vistas a las elecciones de 1998 y 2000, o de la unión que se está conformando en la actualidad desde las últimas elecciones presidenciales de diciembre del 2006, como de las mayorías populares que lo apoyan (relación Líder/masa) y desde luego de las Fuerzas Armadas Nacionales (afianzamiento de las relaciones civiles-militares). Ciertos autores hasta hablarán de autoritarismo en cuanto a las modalidades de ejercicio del poder, al comparar las Constituciones de 1961 y 1999, y los inicios de un culto centrado en la personalidad de un líder. ${ }^{35}$

34 G. Carrera Damas, "Entre el héroe...". Tal Cual, 1 de enero de 2007: "Inés Quintero desnuda a El Bolívar de Carlos Marx". Federico Brito Figueroa: Tiempo de Ezequiel Zamora, Caracas, UCV/EBUC, 1981.

35 Manuel Caballero: "La nueva historia de Venezuela", El Universal, 12 de enero, 2/2004; Jacqueline Clarac de Briceño: El "lenguaje al revés" (Aproximación antropológica y etnopsiquiátrica al tema, Mérida (Venezuela)ULA/GRIAL-CIET/Ed. Dabanata, 2005. Germán Carrera Damas: "En defensa de las bases históricas de la conciencia nacional", El Nacional, 24 de febrero de 2005; Elías Pino Iturrieta: El divino Bolívar. Ensayo sobre una religión republicana, Madrid, Catarata, 2003; y del mismo autor: "La historia oficial" (aquí citado), El Universal, 27 de octubre de 2003. Frédérique Langue: "Petróleo y revolución en las Américas. Las estrategias bolivarianas de Hugo Chávez", Revista Venezolana de Ciencia Política, n. ${ }^{\circ}$ 29, Caracas, enero-junio de 2006, pp. 127-152. Carlos A. Romero: "Chávez, un año en el poder", Venezuela Analítica, 11 de febrero de 2000, http://www.analitica.com Trino Márquez: "Presidencialismo, autoritarismo o culto a la personalidad (Hugo Chávez y el ejercicio del poder)", Revista Venezolana de Análisis de Coyuntura, vol. X, núm. 2, 2004, pp. 57-77, en: www.redalyc.org 
Nos parece más sensato al respecto, y a la luz de la evolución experimentada por la Revolución Bolivariana, insistir en la permanencia en el ideario político venezolano de la idea de un gobernante fuerte, desde la época de la Independencia. Esta visión se funda en la idea de la presidencia vitalicia y del Poder Moral depositados de forma "experimental" en Simón Bolívar a partir del Congreso de Angostura (1819) y luego en la Constitución de la República de Bolivia (1826). El mito del salvador nacional que se sacrifica por su patria en momentos de crisis, para salvarla del caos (figura que $\mathrm{H}$. Chávez va a retomar también ampliándola al mundo entero para salvarlo del "diablo"/imperialismo norteamericano, después de conferirle una dimensión mediática durante su intento de golpe de Estado de febrero 1992), se entronizará luego en posturas políticas que, a pesar del liberalismo, no dejaron de favorecer el personalismo político venezolano y se instala de forma duradera en el pensamiento político venezolano de la última década del siglo XIX, y se vuelve hegemónico en el siglo XX, conviviendo con las tendencias desarrollistas del régimen pérezjimenista y su "Nuevo Ideal Nacional", culminado con la llamada "Va República" en 1999. Junto a este ideario no exento de sentimientos y racionalidad, especialmente en el siglo XIX con los regímenes positivistas (L. Castro Lleiva se refirió al "sentimentalismo moral de la República" y Graciela Soriano al "personalismo político" que surge en ese preciso momento) está la convicción de que el Estado tiene que formar a unos ciudadanos "virtuosos" y el papel fundamental de la transmisión de la historia a lo largo de un proceso refundador de la nación. ${ }^{36}$

El examen de las propuestas planteadas por Bolívar y algunos de sus contemporáneos en torno a la idea de dictadura en un régimen republicano o sea caracterizado en un principio por la soberanía popular, una declaración de derechos universales, el estado de derecho y la separación de los poderes públicos, permite aclarar varias medidas "de emergencia" que fueron tomadas durante el periodo comprendido entre 1811 y 1830 en provecho de formas de gobierno personalistas, de corte autoritario, que permitieran superar el dilema de crear un nuevo orden político en una situación de crisis ocasionada por una parte por la misma guerra de Independencia y por otra, por las pugnas internas y la disgregación de Colombia. La dictadura como recurso de gobierno ha sido utilizada por Miranda en 1812 y por

36 Elena Plaza: "La idea del gobernante fuerte en la historia de Venezuela (1819-1999)", Politeia, vol. 27, n. ${ }^{\circ}$ 27, Caracas, julio de 2001, disponible en Scielo Venezuela. 
Bolívar de manera intermitente entre 1813 y 1830. Dio pie a una serie de discusiones - acerca de las modalidades de gobierno- enmarcadas dentro de las constituciones promulgadas durante ese periodo y de repetidos y frustrados intentos por aplicar modelos de república en Venezuela en aras del nuevo marco de referencia, el Estado-nación. ${ }^{37}$ La Primera República nació bajo los auspicios de la representación tradicional y del pactismo (véase el Acta de Independencia del 5 de julio de 1811). Ante la presencia de focos realistas en Caracas y Valencia, el Congreso tuvo que tomar medidas "por el peligro en que se halla(ba) la patria" y promulgar una resolución que lo autorizaba "para obrar libremente", acordando que el Ejecutivo pudiera actuar "en todo lo relativo a la seguridad y la tranquilidad, sea la salud del pueblo la suprema ley". ${ }^{38}$

Juan Carlos Rey señala, por otra parte, que esta disposición y los poderes extraordinarios que de ella se derivan sirvió también para controlar a los realistas. Después de la derrota de éstos, el Congreso volvió a asumir sus facultades, mientras Francisco de Miranda insistía, al igual que muchos partidarios de la república, en que se estableciese formalmente una constitución, como única vía para garantizar libertad y seguridad. En diciembre del mismo año será promulgada la Constitución Federal de los Estados Unidos de Venezuela, inspirada en parte en la de Filadelfia. Sin embargo, la promulgación de la Constitución no trajo consigo la anhelada paz política, de ahí una nueva concentración de poderes a favor del ejecutivo, que culmina el 23 de abril, cuando ese Ejecutivo nombra a Francisco de Miranda general en jefe de la Confederación Venezolana. Se le faculta para encabezar las acciones en el frente y tomar decisiones como cabeza principal del Estado y de la República, características que son las de una dictadura que pretende mantener el hilo constitucional aunque J.C. Rey señala que no se dieron verdaderamente las condiciones de ejercicio de un poder absoluto en el caso de Miranda. No se acató formalmente el acto del Ejecutivo por lo cual éste se reunió con el Gobierno de Caracas el 19 de mayo para "aclarar y determinar ciertos puntos sobre el mando militar, y la armonía y cooperación que el gobierno político y civil debe observar con

37 Juan Carlos Rey: "La "condición de Bolívar" o la imposibilidad de la democracia: sobre la teoría de la dictadura latinoamericana", Politeia, n. ${ }^{\circ} 11$, Caracas, 1982, pp. 197-250.

38 J. C. Rey: "De la ilusión republicana a la realidad personalista. Análisis de las ideas, la legislación y la acción en torno a la dictadura y los estados excepcionales a partir del pensamiento de El Libertador", Anuario de Estudios Bolivarianos, Año XII, número 13, Caracas, 2006, pp. 91-134. François-Xavier Guerra: Modernidad e Independencias, Madrid, MAPFRE, 1992. 
él" y ampliar los poderes absolutos otorgados por el Congreso, en un contexto sin embargo de inestabilidad por la ofensiva realista y especialmente la arremetida de Monteverde. La ley marcial, con facultad de nombrar autoridades militares y subordinando el poder civil a éstas se promulgó el 19 de julio, aunque con el siguiente señalamiento: "la salud del Pueblo es Suprema Ley y deben callar todas las demás que no sean necesarias para salvar la Patria del peligro en que se halla. El armisticio consagró el fracaso de estas disposiciones, así como la insistencia de Miranda en consultar los "Gobiernos de las provincias que se hallan en libertad". Sin embargo, no viene al caso entrar aquí en la discusión planteada en adelante acerca de la capitulación (firma de San Mateo) y la suspensión de Fernando Miyares como gobernador y capitán general por Monteverde en provecho del vencedor (Monteverde). ${ }^{39}$

Considerar la ambigüedad del concepto de dictadura y la aplicación azarosa de los correspondientes decretos llevarían a una reflexión de tipo filosófico e institucional que tampoco nos corresponde iniciar aquí. En cambio, resulta más sugerente considerar las declinaciones sucesivas del principio enarbolado por el Congreso con motivo de la primera dictadura del Libertador. J.C. Rey señala que "desde diciembre de 1812, Bolívar en Cartagena criticaría el sistema de gobierno que había sido implantado por los republicanos en Venezuela y lo llegaría a considerar como una de las principales causas de la pérdida de la Primera República”. Recordemos que en el Manifiesto de Cartagena, Bolívar plantea la necesidad de un gobierno fuerte que se ajustara a las circunstancias (facciones y guerra interna) y no solamente en códigos. De ahí las instrucciones muy pragmáticas que le encaminó al doctor Cristóbal Mendoza antes de iniciar la Campaña Admirable con el fin exclusivo de restablecer el Gobierno y las autoridades republicanas de 1812 (abril del 1813). Las ambigüedades y limitaciones impuestas en ese aspecto por el Gobierno neogranadino no le impidieron a Bolívar ejercer un poder absoluto de facto. De tal forma que se promulgó

39 El Acta de Independencia (1811), así como varios textos del periodo, pueden consultarse en http://www.anhvenezuela.org/ Textos oficiales de la Primera República de Venezuela, Caracas, Ediciones de la Presidencia de la República, 1983, pp. 107-108 y "Conferencia del General Miranda, Generalísimo del Ejército Republicano de Venezuela, con los miembros del Poder Ejecutivo Federal, con los del Gobierno Provincial de Caracas y de la Cámara de Representantes de la misma Provincia, el 19 de mayo de 1812", en José Blanco y Ramón Azpúrua (comps.): Documentos para la vida pública del Libertador, tomo III, Caracas, Ediciones de la Presidencia de la República, 1983, p. 667 ; J.C. Rey: "De la ilusión republicana a la realidad personalista...". Gaceta de Caracas, 1 de noviembre de 1811 . 
el Decreto de Guerra a muerte ( 15 de junio) y que empezó a ejercer la autoridad suprema en Caracas, tras su ocupación el 7 de agosto. ${ }^{40}$

Ante la imposibilidad de reunir a los miembros del Gobierno y del Congreso, Bolívar terminó consultando a varios "hombres de saber y conocimiento" acerca de la forma de gobierno transitorio. Tanto Javier Ustáriz como Miguel José Sanz coincidieron en conferirle los poderes absolutos al Libertador hasta conseguir la paz así como la unión con Nueva Granada. Bolívar asumió entonces la dictadura subordinando las autoridades civiles de la provincia a la autoridad del teniente coronel García de Serna (diciembre de 1813) aunque no por eso aceptó ser reconocido como la "autoridad suprema de la Confederación" si no fuese mediante elección. ${ }^{41}$ Esta aparente renuncia de Bolívar a los poderes dictatoriales apareció a todas luces con motivo de la asamblea que se convocó en Caracas el 2 de enero de 1814, "primer acto de libertad y republicanismo" y "solemne reconocimiento de la soberanía del Pueblo representada en esta honorable Asamblea". Terminó aceptando el mando "sujeto a la voluntad del pueblo" para hacer frente al ejército realista durante el año 1814. Refugiado en Carúpano después de la pérdida de la Segunda República en 1814, el Libertador empezó a poner en duda la capacidad moral de los pueblos para decidir sobre su propio beneficio. En mayo de 1817, con motivo de la instalación del Congreso de Cariaco, Bolívar es reconocido como "Jefe Supremo de la República", lo que implica, como señala J.C. Rey, la "continuidad de los poderes dictatoriales que le habían sido conferidos por la asamblea caraqueña de 1814". Sólo los entregará en febrero de 1819, en el Congreso de Angostura. ${ }^{42}$

Con esta última Asamblea congresual se abre un nuevo marco constitucional, fuente para Bolívar "de la autoridad legítima, depósito de la autoridad soberana y árbitro del destino de la nación". Allí pronuncia su conocido discurso desarrollando sus ideas acerca del gobierno republicano y de las elecciones (un gobierno central compuesto por cuatro poderes públicos —ejecutivo, legislativo, judicial y moral-, elecciones necesarias, temores ante la permanencia de un solo individuo en el poder y la instauración de la tiranía), de la soberanía e igualdad del pueblo (a la manera inglesa), de la división de poderes, de las libertades individuales, de la abolición de los

\footnotetext{
40 J.C. Rey: "De la ilusión republicana a la realidad personalista...".

41 Ibidem. Véase correspondencia de Bolívar al respecto, reproducida en parte en este trabajo (a Manuel A. Pulido o a los miembros de la municipalidad de Barinas).

42 Ibidem.
} 
privilegios y de la esclavitud y proponiendo un nuevo proyecto de Constitución. Después de conseguir la liberación de Nueva Granada, regresa a Angostura en diciembre para plantear esta vez la creación de Colombia. El mando supremo quedó depositado en él como presidente, lo que le permitió reunirse más adelante con Morillo para firmar el tratado de regularización de la Guerra (1820). El nuevo Congreso reunido en Cúcuta en 1821 ratificó a Bolívar en el cargo de presidente de la República de Colombia y promulgó una nueva Constitución esbozando "las características clásicas de la dictadura constitucional", siempre y cuando se amenazara la seguridad de la nación. A partir de este año, el gobierno estuvo en manos del vicepresidente Francisco de Paula Santander, mientras el Libertador marchaba hacia el sur (campaña del general Sucre, entrevista con San Martín, con quien tuvo discrepancias acerca del principio de "gobierno unipersonal"). De hecho el Congreso peruano también lo investirá del título de dictador (1823-1826).

Además de sellar la independencia del Perú, Bolívar elabora durante ese periodo un nuevo proyecto constitucional para Bolivia, "pero con miras a que fuera adoptado por todas las provincias liberadas" y siguiendo el modelo republicano planteado en Angostura, fortaleciendo el Ejecutivo y proponiendo una presidencia vitalicia en la cual el primer mandatario podría nombrar a su sucesor (en contra, esta vez, de lo planteado en Angostura, de desconfianza hacia la perpetuidad del poder en manos de un individuo). Mientras se va conformando el gobierno de Colombia (18221825), la guerra toca a su fin en Venezuela con las batallas de Carabobo (1821) y Puerto Cabello (1823). Varios congresos reunidos en Bogotá contribuyeron entonces en reestructurar la vida civil de la República. ${ }^{43}$

Con las disensiones internas y el estallido en Venezuela de "la Cosiata" (abril de 1826) se desconoció en parte el gobierno de Bogotá por varias municipalidades mientras se le confieren a José Antonio Páez poderes dictatoriales, siendo por otra parte el único recurso admitido por Bolívar para salir del "caos" y fundar de nuevo el "pacto social", si consideramos su carta a Santander fechada el 14 de octubre de 1826: "Esta magistratura [la dictadura] es republicana", afirma el Libertador. De ahí el decreto que promulga con fecha del 23 de noviembre de 1826 (fuente de conflictos con Santander) y la legitimidad que le otorga a Páez, subordinándolo sin embargo al gobierno de Bogotá. Antes de la Convención de Ocaña, convocada

43 Ibidem. 
para el 9 de abril de 1828 con el fin de promulgar una nueva Constitución para la República, insiste en la necesidad de un Ejecutivo fuerte para terminar asumiendo el "poder supremo de la república" del Estado bajo el título de Libertador Presidente, recuperando la soberanía que le había sido arrebatada al pueblo por un gobierno ineficiente (decreto del 27 de agosto de 1828) pero generando de esta forma el rechazo a su persona y acción más allá de las fronteras de Colombia y la decisión final de Venezuela de separarse de ésta, confirmando la inadecuación del modelo republicano a las circunstancias de la guerra y más adelante del desmembramiento de Colombia, y confortando la peculiar conjunción que se iba a dar en Venezuela entre institucionalidad y personalismo político. Para el Libertador, la dictadura no fue en efecto sino un recurso constitucional y funcional, y la soberanía del pueblo un concepto muy evolutivo, originado en la necesidad de actuar de acuerdo a unos principios pero también a las circunstancias. ${ }^{44}$

\section{Conclusión tentativa ¿Será posible contrarrestar el mito?}

Este desfase y aparentes contradicciones del pensamiento del Libertador entre la estructura constitucional lograda y la realidad política, su aguda conciencia del fracaso y sus esfuerzos por preservar la visión heroica de la gesta independentista, tuvieron como consecuencia un debilitamiento de la legitimidad constitucional y la afirmación de los caudillos, característica de la historia política de Venezuela a lo largo del siglo XIX y que no terminaría sino hasta principios del XX, con el gobierno de Cipriano Castro. La contrapartida del ejercicio autoritario del poder la encontramos en la voluntad reiterada de los mandatarios de cuidar la manera como se iba escribiendo la historia del país. Como subrayó Elías Pino Iturrieta:

Desde la época de Páez, cuando se encargó a Baralt y a Díaz el Resumen de la Historia de Venezuela, se ha intentado la factura de una versión del pasado que cuente con la aprobación de los gobiernos. Tal debe ser el origen de la llamada historia oficial, que llegó a la cúspide en las conmemoraciones tendenciosas de Guzmán.

44 "Manifiesto del Libertador sobre la instalación del Congreso constitucional, el cese del gobierno dictatorial y el anuncio del término de su carrera política”, Bogotá, 20 de enero de 1828, citado en J.C. Rey: "De la ilusión republicana a la realidad personalista...”. Aníbal Romero: La idea de la política en el pensamiento del Libertador, Caracas, Ateneo de Caracas, 1985, p. 133. Aníbal Romero: "Bolívar como héroe trágico", Anuario de Estudios Bolivarianos, Año IX, número 10, Caracas, 2003, pp. $75-123$. 
Data de esos tiempos la obra de González Guiñán, ocupada en registrar las glorias del Partido Liberal. Más tarde, la Academia de la Historia y la Sociedad Bolivariana se preocuparon por cuidar la circulación de textos "convenientes". En adelante metió el ojo el Ministerio de Educación, con el objeto de evitar la aparición de manuales heterodoxos. Pero, debido a la fundación de las escuelas universitarias de Historia, se desarrolló un entendimiento gracias al cual se ha podido atesorar una memoria más ajustada a la verdad y a la honradez profesional. Desde el advenimiento de Chávez venimos sufriendo la mayor arremetida de la historia oficial. El propio primer magistrado se ha convertido en historiador, para traficar con una lección sobre el pasado que traspasa la barrera usual de los libros debido a su difusión a través de los medios de comunicación. Ya hubiera deseado Picón Salas una tribuna tan ubicua. Gracias a la transfiguración del presidente en catedrático, se ha ido filtrando un conocimiento de los antecedentes de la nación en el cual se alimenta una versión del pasado y de sus protagonistas como no pasó antes jamás. En lo que afirma se sustenta la última edición de la historia oficial, acaso más perjudicial y más anodina que las historias oficiales de antes debido a su olímpica miopía y a su empeño en hilvanar estereotipos de los cuales se produzca la legitimación de la "revolución". Se pudiera escribir un periódico entero sobre las simplezas de don Hugo metamorfoseado en don Mariano, para comentar lo que no permiten ahora las limitaciones de espacio. Pero también para entender, en caso de que se pueda, cómo ha sido posible que muchos historiadores profesionales se hayan entusiasmado con un disparate tan clamoroso. ${ }^{45}$

Esta aproximación a la historia reciente e incluso inmediata de Venezuela haciendo hincapié en una historia regresiva contribuye a poner de relieve, más que cualquier otra periodización histórica, la necesidad de invertir la relación tradicionalmente establecida entre historia y memoria, y de tomar en cuenta lo no dicho de la historia. La oposición tradicional entre una historia crítica, ubicada del lado de la ciencia, y una memoria fundada en fuentes contestables o forjadora de emociones ya no tiene razón de ser en esta perspectiva. Mientras la historia tiende a "nutrirse" de las herramientas y de los métodos de otras disciplinas, la problematización de la memoria lleva a considerar con una mirada crítica el concepto mismo de memoria y, sobretodo, al tener en cuenta el "reverso" de la historia, los silencios y los olvidos, dicho de otra forma, las sensibilidades y visiones del mundo (incluyendo las del historiador, que no dejan de influir en la interpretación adelantada y hasta en la elección de fuentes). La importancia del testigo y especialmente de las fuentes orales, hemerográficas, digitales (Internet) en el proceso de escritura del tiempo presente posibilita la elaboración de una historia de la memoria y por esta razón, otra manera de escribir la historia

45 Elías Pino Iturrieta: "La historia oficial”, El Universal, 27 de octubre de 2003. 
abriéndola en especial a otros actores. En el caso venezolano, y si retomamos la argumentación de Elías Pino y ubicándonos en el tiempo largo:

... la revolución está empeñada en la fábrica de una memoria diversa de la sociedad. Chávez no quiere exhibirse como una caprichosa imposición personal, sino como el producto de los errores del pasado y como el vengador de un oprobioso ayer. De allí sus habituales incursiones hacia los tiempos idos, con el objeto de elaborar un insólito elenco de santos y villanos que conduzca a su desembocadura y a la preeminencia del ejército sobre el civismo. De allí su apología de las matazones del siglo XIX, sus machaconas referencias a la Independencia y su subestimación del trabajo pacífico y silencioso que hizo la sociedad para construir el Estado Nacional. Ve la historia patria como la vio Cipriano Castro y como la vio Gómez: lanzas, espadas y gritos en reemplazo de la civilización morigerada.

La historia del tiempo presente y el papel sumamente importante devuelto a las sensibilidades como respuesta ante determinado acontecimiento, tiende a alterar y a relativizar la relación con el pasado, la visión que se tiene del mismo, así como el análisis adelantado al respecto. También entra en juego la "escala" del acontecer, de ahí la necesidad de enfocar el contexto de estas sensibilidades dentro del proceso de "recepción del acontecimiento". Lo que es acontecimiento — por definición, mediático- para un individuo o una generación, no lo es necesariamente para otro(s). Ahora bien, el historiador del tiempo presente inscribe su proyecto historiográfico en el tiempo largo, de ninguna manera limita los contornos de su objeto al instante. Siempre en el caso que nos interesa aquí, el de la República Bolivariana, la designación de Venezuela con este nombre, sería, según E. Pino, una

...mutilación de la conciencia nacional, en la medida en que el bautizo constitucional reduce la evolución de la sociedad al lapso dorado de la Independencia y a la acción de un solo artífice. La designación echa a la basura el periodo colonial y los esfuerzos del pueblo luego de 1830, una escandalosa negación que la sociedad ha consentido, por desdicha.

Desde la perspectiva de uno u otro "bando", son los entrecruzamientos de historias de vidas y de destinos colectivos los que contribuyen en fundar el sentido que se le da al acontecimiento y, particularmente, el "ajuste cultural" del mismo, o sea las aprensiones e imágenes sociales que de él se derivan. El historiador profesional privilegia por lo tanto una práctica consciente de si misma, naturalmente confrontada con una constante revisión crítica; dicho de otra manera, una "escritura que se encuentra en tensión con las prácticas", que incluye una peculiar vigilancia para con la ins- 
trumentalización de la historia, y el "peligro multiforme de reutilización simbólica" que acecha los escritos de los historiadores, las distorsiones recuperadoras inherentes a un uso abusivo de la historia. Siempre en el caso que nos interesa, y ante semejante uso de la historia en provecho de una verdadera "religión republicana", la "chavología" que tan de moda se puso entre turiferarios etnocentristas de una izquierda autoritaria en vías en extinción en Europa debería ser en realidad

...una ciencia compartida, o una especie de deporte nacional, en la medida en que necesariamente se refiere a la entronización de un personalismo en nuestros días. ${ }^{46}$

La utilización del pensamiento de Bolívar, el significado que se le achaca a sus acciones e ideas no puede desligarse de un contexto y de un momento histórico. De lo contrario no desemboca sino en un uso anacrónico y hasta arbitrario del pensamiento del Libertador. Como lo puntualizó el propio Bolívar:

... Si algunas personas interpretan mi modo de pensar y en él apoyan sus errores, me es bien sensible, pero inevitable; con mi nombre se quiere hacer en Colombia el bien y el mal, y muchos lo invocan como el texto de sus disparates. ${ }^{47}$

Tener en cuenta las representaciones y los imaginarios políticos nos lleva, por consiguiente, a una interpretación algo matizada de las últimas "entregas" de la historia oficial en la República Bolivariana. Contribuye en especial a relativizar el cariz dictatorial e incluso totalitario denunciado por los detractores del régimen. El gobierno de Chávez no es un gobierno dictatorial y menos todavía un gobierno totalitario a la cubana, puntualizó Teodoro Petkoff, al indicar que tampoco se trataba de un régimen democrático sino de un gobierno propenso a fomentar un "populismo distributivo y munificente". ${ }^{48}$ El gobernante fuerte, por no decir el "gendarme necesario" ejemplificado por L. Vallenilla Lanz, es el trasfondo ineludible de la mayoría de las teorías políticas ideadas durante el periodo de Independencia. Este principio hegemónico en el ideario político venezolano retoma clara-

46 Miguel de Certeau: L'écriture de l'histoire: Paris, Gallimard, 1975, p. 61. Luc Capdevila: "Les temporalités de l'événement en histoire", en Que se passe-t-il? Evénements, sciences humaines..., pp. 79-89. François Bédarida: "Les usages de l'histoire et la responsabilité de l'historien”, Congreso Mundial de Historia, Oslo, 2000, http://www.oslo2000.oio.no Elías Pino: "Los mitos políticos...", en G. Carrera Damas; C. Leal Curiel et alt.: Mitos políticos...

47 Bolívar a Antonio Leocadio Guzmán, Popayán, 6 de diciembre de 1829, Obras completas, La Habana, Editorial Lex, 1947-1950, T. II, pp. 836-837.

48 Teodoro Petkoff: Dos izquierdas, Caracas, Alfadil, 2005, pp. 37-38. 
mente la idea de una presidencia vitalicia y de un "poder moral" del que fue depositario Simón Bolívar después del Congreso de Angostura (1819) y luego por la Constitución de Bolivia (1826). ${ }^{49}$

El paradigma heroico, junto al mito del salvador de la patria/nación (procedente del sector militar) encuentra especiales ecos en coyunturas de crisis o de caos. Hugo Chávez no dejó de insistir en estas circunstancias al evocar la figura del "diablo" en la ONU y las consecuencias nefastas del imperialismo norteamericano. Estos dos elementos, el paradigma heroico y el mito del salvador de la nación, participan de esas posturas políticas de cuño personalista aunque también de gran difusión en los medios liberales, que van a dominar en el panorama político criollo desde fines del XIX. Con el siglo XX se vuelven hegemónicas al compaginarse con veleidades desarrollistas tales como las llevó a la práctica el régimen pérezjimenista con su "nuevo ideal nacional". Esta reivindicación sumamente ambigua que enaltece, al menos en un primer momento, el ejercicio de la democracia (participativa) y favorece el reconocimiento de líderes anti-partidistas (aspecto neo-populista de $\mathrm{H}$. Chávez), culmina a partir de 1999 con el advenimiento de la Va República y el recordatorio no menos presente de la figura del "buen revolucionario" junto a un milenarismo convertido en "revolucionarismo secular", tal como lo denunció precisamente Carlos Rangel en su libro publicado en 1976, Del buen salvaje al buen revolucionario. ${ }^{50}$

Sensibilidades (políticas), pasiones encubiertas y también modos de racionalidad diversos conforman ese "personalismo político" difícil de clasificar dentro de una tipología precisa o sólo recurriendo a los usos desvelados por el lenguaje - según Graciela Soriano- y fundados en un ejercicio personal del poder aunque de igual manera en la convicción de que le corresponde al Estado formar a ciudadanos "virtuosos" y orientar la transmisión del relato histórico a lo largo de un proceso que vuelve a fundar la nación. Esta escritura sesgada de la historia — historia oficial— llegó en este sentido a instrumentalizar la figura de Libertador en el marco de esa revisión mítica y maniqueísta. En diciembre de 2007-enero de 2008 se abrió otra etapa en la santificación del héroe, con la creación de una comisión presidencial destinada a investigar las causas de la muerte de Bolívar (se le hubiera asesinado/envenenado, por los "oligarcas" venezolanos y

49 E. Plaza: "La idea del gobernante fuerte...", pp. 7-24.

50 Carlos Rangel: Del buen salvaje al buen revolucionario. Mitos y realidades de América Latina, Madrid, Gota/Fundación Faes, 2007 (1976). 
colombianos, o sea que no hubiera muerto de enfermedad, según el mismo presidente Chávez). En cuanto a las cenizas del Libertador, conservadas en el Panteón Nacional, hasta se puso en duda su autenticidad. Otro mito, el del complot, tiende a reunir el héroe del pasado con el del presente y cerrar de esta forma un ciclo heroico: en numerosas oportunidades, H. Chávez denunció las conspiraciones urdidas desde Estados Unidos con el fin de asesinarlo, siguiendo en esto el modelo discursivo cubano (aspecto clave en los discursos de Fidel Castro). Este tema salió de nuevo a relucir durante los conatos de guerra con Colombia a principios del año 2008 y en los siguientes meses, cuando, por este motivo, canceló su participación en la Cumbre Latinoamericana. E. Pino recuerda que en esa oportunidad no se intentó sino crear un paralelismo histórico, insinuando que Santander había atacado a Bolívar, así como Uribe lo podría hacer con Chávez. ${ }^{51}$

Ante la perspectiva de un nuevo referendo sobre la enmienda constitucional (acerca de la reelección continua del presidente), se fundó el comando "Angostura", iniciativa de la organización Ciudadanía Activa para rescatar el pensamiento del Libertador Simón Bolívar y trascender los espacios partidistas de la oposición. Mientras tanto se recibió en Caracas al presidente de Cuba, Raúl Castro, quien se llevó una réplica de la espada de Bolívar y el Gran Collar de la Orden Libertador, máxima distinción que otorga el Gobierno venezolano.En esa oportunidad, el presidente Chávez recurrió nuevamente a las palabras del Libertador, refiriéndose a discursos del año 1825, que antecedieron a la creación de Bolivia: "Bolívar propone la presidencia vitalicia a la Constituyente de Bolivia. Esa es una fórmula innovadora". En el mismo momento, sus defensores invirtieron los términos del "debate" al denunciar los usos de los textos del Libertador por la oposición - que se dedicaría a "cercenar sus discursos y distorsionar sus proclamas"- y "la tijera de estos neo-mantuanos sin mantuanaje", en un reconocimiento implícito de la aristocrática clase social del Libertador. ${ }^{52}$

51 El Universal, 29 y 30 de enero de 2008: http://politica.eluniversal.com/2008/01/30/ pol_art_comision-sustanciara_693257.shtml Reinaldo Rojas: "El retorno de los héroes: el discurso político de Hugo Chávez y el proceso constituyente en Venezuela de 1999" (2000), inédito. E. Pino Iturrieta: "La historia oficial...". Graciela Soriano de García Pelayo: El personalismo político hispanoamericano del siglo XIX, Caracas, Monte Ávila Editores, 1996 y: “Aproximaciones al personalismo político hispanoamericano del siglo XIX.", en Revista del Centro de Estudios Constitucionales, n. ${ }^{\circ}$ 7, Madrid, septiembre-diciembre 1990, pp. 203-218. Georgely Morín: "El Libertador es un cangrejo”, Tal Cual, 17 de diciembre de 2008. Juan Pablo Arocha: "Resucitar a Bolívar", Tal Cual, 18 de diciembre de 2008.

52 David Ludovic Jorge: "Rescatar a Bolívar", Tal Cual, 19 de diciembre de 2008. Andrés Rojas Jiménez: "Chávez dijo que Simón Bolívar estuvo a favor de la presidencia vitalicia”, El Nacional, 14 de diciembre de 2008. Earle Herrera: "Bolívar cercenado", El Mundo, 15 de diciembre de 2008. 
A finales de 2008, la polémica acerca de la muerte de S. Bolívar, algo zanjada por la actualidad, arribó sin embargo a España por medio de un artículo publicado en El País, donde se retoman elementos del historial médico de Bolívar, debidamente recordados por expertos en historia de la medicina, en contra de la hipótesis del crimen y conjura criminal tal como la sustentaron "asesores" de la comisión presidencial. En la conspiración para asesinar a Bolívar habrían participado "los gobiernos de Estados Unidos, Inglaterra y España”. El propósito de los historiadores profesionales partidarios del gobierno se ve sin embargo mucho más prudente, como se evidencia en la declaración de Pedro Calzadilla, director del recién creado Centro Nacional de Historia y citado en este artículo: "Nuestro objetivo es democratizar la memoria colectiva nacional (...) Queremos privilegiar la perspectiva de los excluidos, negros, indios, mujeres, pobres", frente a la historiografía tradicional, "hecha a imagen y semejanza de los sectores poderosos". ${ }^{53}$

No se puede hacer caso omiso sin embargo del riesgo de instrumentalización de prácticas historiadoras avaladas en adelante por el Centro Nacional de Historia. Tampoco se puede obviar la recurrencia del fenómeno personalista en la historia de Venezuela — siguiendo unas pautas del "Padre de la democracia" Rómulo Betancourt, que él no hubiera desmentido, se celebró en 2008 el centenario de su nacimiento-, que asomó de nuevo a principios de ese mismo 2008, con el (auto) nombramiento de Hugo Chávez como presidente del Partido Socialista Unificado de Venezuela (PSUV). Sobre este particular y para cerrar esta polémica inconclusa, tan sólo recordaremos a Tomás Lander, portavoz del pensamiento liberal del siglo XIX, y la crítica contundente que hizo a las tendencias personalistas del "déspota Bolívar", subrayando al mismo tiempo la extrema dificultad de contrarrestar el mito bolivariano, y más cuando lo sustenta otra dimensión del imaginario y de la práctica política criolla: el pretorianismo, también muy olvidado de la historia oficial y de sus avatares mediatizados. 